\title{
RISK MANAGEMENT OF SUGAR PRODUCTION DUE TO THE MAGNITUDE OF LOSSES (CASE STUDY OF PT PERKEBUNAN NUSANTARA X)
}

\author{
Ahmad Zainuddin")1, Intan Kartika Setyawati*), and Rudi Wibowo*) \\ *) Agribusiness Study Program, Faculty of Agriculture, University of Jember \\ Jl. Kalimatan 37 Kampus Tegal Boto Jember 68121
}

\begin{abstract}
High sugar consumption cannot be fulfilled by domestic sugar production. The reason is that the performance and efficiency of the national sugar mills (PG) are still relatively low. Measurement of efficiency of sugar mills can be conducted by counting the sugar losses. This study aims to (1) to analyze the value of loss index and its implications on the efficiency of sugar mills;and (2) to assess the risk due to losses. Primary and Secondary data were used in this study containing annual data of sugar mills performance indicators in PTPN X such as Overall Recovery (OR), Boiling House Recovery (BHR), Mill Extraction (ME), the amount of bagasse, the amount of filter cake, and the amount if molasses at sugar cane factory (period of 2011-2015). The data were analyzed by evaluative descriptive analysis, index calculation, and risk assessment using Failure Mode and Effect Analysis (FMEA) method. The analysis shows that the losses produced by sugar mills in Indonesia are still quite high around 2.60-2.88\%. This level of losses shows the performance of sugar mills is inefficient and causes financial losses in sugar mills. Production risk assessment due to losses shows a high level of risk. Therefore, sugar mills must have a program to reduce its level of losses to the minimum level $(<2 \%)$. Meanwhile, sugar mills must have programs to utilize losses to be value-added co-products.
\end{abstract}

Keywords: losses, FMEA, efficiency, performance, sugar industry

\begin{abstract}
Abstrak: Kebutuhan konsumsi gula yang tinggi tidak dapat dipenuhi oleh produksi gula nasional. Penyebabnya adalah kinerja dan efisiensi pabrik gula $(P G)$ nasional yang masih relatif rendah. Pengukuran efisiensi pabrik gula dapat dilakukan dengan menghitung gula yang hilang (losses). Penelitian ini bertujuan untuk (1) menganalisis nilai indeks losses dan implikasinya terhadap efisiensi pabrik gula; dan (2) menilai besaran risiko akibat adanya losses. Data yang digunakan adalah data primer dan sekunder berupa data tahunan indikator kinerja pabrik gula di PTPN X seperti data Overall Recovery (OR), Boiling House Recovery (BHR), Mill Extraction (ME), jumlah ampas, jumlah blotong dan jumlah molase pada PG (periode 2011-2015) . Data dianalisis menggunakan analisis deskriptif evaluatif, perhitungan indeks dan penilaian risiko dengan metode Failure Mode and Effect Analysis (FMEA). Hasil analisis menunjukkan bahwa losses yang dihasilkan oleh pabrik gula di Indonesia masih cukup tinggi, berkisar antara 2,48-2,88\%. Tingkat losses ini menunjukkan kinerja pabrik gula yang belum efisien dan dapat menyebabkan kerugian pabrik gula. Penilaian risiko produksi akibat losses menunjukkan tingkat risiko yang tinggi. Oleh karena itu, pabrik gula harus memiliki program untuk menekan tingkat losses sampai pada taraf minimalnya $(<2 \%)$. Sementara itu, pabrik gula harus mempunyai program untuk memanfaatkan losses menjadi ko-produk yang bernilai tambah.
\end{abstract}

Kata kunci: losses, FMEA, efisiensi, kinerja, pabrik gula

\section{INTRODUCTION}

Sugar is one of the important and strategic commodities. The sugar industry in Indonesia is able to absorb a large workforce starting from on-farms to off-farms, has forward and backward linkages, and can improve the welfare of the community (Fahriyah et al. 2012; Neves et al. 2009; Susilowati and Trinaprilla, 2012; Subiyanto, 2014).

\footnotetext{
${ }^{1}$ Corresponding author:

Email: nidduniaz.ahmad@gmail.com
}

The increasing number of population every year has an implication for the increase of national sugar consumption requirement (Hartono, 2012; Sawit et al. 2010; Marta, 2011). If viewed from the supply side, national sugar production is still unable to meet consumption needs due to the decline in sugar cane productivity and low efficiency of the sugar mills. This low efficiency is due to the old sugar mill machinery resulting in decreased sugar production; moreover, the technology used also lags behind other countries, and this has implications for the low quality of sugar (Sugianto, 2007; Bantacut, 2010; Tinaprilla and Ariesa, 2012; Cahyati, 2012; Tayibnapis et al. 2016). 
Currently, the national sugar consumption is reaching 5.8 million tons, and it is predicted to increase by 6.6 million tons - 7.0 million tons in the next 5 years. The direct consumption requirement for household consumers is currently estimated at 3.0 million tons of white crystal sugar (GKP), and the rest is consumption requirement (indirectly) for industries in the form of refined crystal sugar (GKR) (Kementerian BUMN RI, 2016). In per capita calculation, with a population of around 240 million, sugar consumption is at $22 \mathrm{~kg} /$ year or slightly higher than the per capita consumption of the world community. The high national sugar consumption clearly is clearly "homework" for the government, farmers, sugar mills, and all stakeholders of the national sugar industry.

Meanwhile, the current national sugar production still does not meet the needs of sugar consumption(Supriyati, 2011). Indonesia's sugar production currently stands at only 2.69 million tons or $45 \%$ of national sugar demand. The total production of sugar, about 1.45 million tons are produced by the state-owned enterprises, and the rest is by the private-owned enterprises (Kementerian BUMN RI, 2016).

The absence of national sugar consumption and production have "pushed" and will continue to "push" the national sugar price level, especially with seasonal sugar market patterns, wide areas of distribution of sugar consumption, limited land and technology resources, oligopolistic market structure and low performance of sugar mills which is still not as good as the performance of sugar mills in other sugar producing countries such as Brazil, India and Thailand (Jati, 2013). In turn, the national sugar price tends to be higher than that of imported sugar. In general, the picture shows that the national sugar industry is not competitive. Decreased sugar production, increased sugar consumption and low efficiency of sugar mills are the major problems that need to be solved (Baghat, 2011).

The critical problem that makes the performance of the national sugar industry unoptimal is the performance of the sugar mills which is still inefficient. In general, the current condition of sugar mills especially for almost all sugar State-Owned Enterprises (SOEs) still experience problems of production inefficiency (Bantacut, 2013). Most of sugar mills owned by SOEs are filled with old milling machines. 43 SOE sugar mills are only capable of having a milling capacity of 160,560 tons of cane per day (TCD). This condition is still far below when compared with Thailand whose production has reached 940,000 TCD from its 50 sugar mills.

Inefficiency is also seen from the low performance of the machine in which a lot of heavy sugar is mixed with the byproducts of sugar mills such as molasses, bagasse, and blotong. Subiyono (2014) states that the latent problem that makes the performance of the sugar industry unoptimal is the inefficiency in the sugar mills. If viewed from the side of processing of sugar mills (off-farms), almost all sugar mills owned by SOEs experience inefficiency. Most of the state-owned sugar mills still use old machines; in addition, their milling capacity is only around 3,500 tons of sugar cane per day (TCD), so they cannot reach the target efficiently. Unoptimal engine performance can make the sugar content to be attached to byproducts from the mills, such as molasses (molasses), bagasse, and blotong and unknown losses. The lost sugar contents are called the losses.

One of the indicators to measure the performance of sugar mills is seen from the level of losses produced. The high losses indicate the level of performance and efficiency of the sugar mills. Therefore, it is necessary to analyze the loss index and its implications for the performance and efficiency of the national sugar mills. Studies on the economics of sugar cane processing losses have been done. Wibowo (2007) stated that the performance of sugar mills in East Java is generally still below the standard. The performance indicators of the milling of the East Java Sugar Mills stated in ME (mill extraction) and BHR (boiling house recovery) are still below the standard. The average sugar loss of the sugar mills in East Java in 2003 (\% of sugar cane was lost in the pole) reached $2.39 \%$ or 1.6 times higher than the allowable percentage (1.5\%).

Sharma and Kumar (2015) also conducted loss analyses on mills in India. The results show that the losses produced by the sugar mills in India amounted to $2.07 \%$ of the total milled cane. It is known in detail that the sugar attached to molasses, bagasse, blotong and unknown losses reached $66.94 \%, 25.34 \%, 2.89 \%$ and $4.83 \%$ respectively.

This research is a development of researches on the amounts and sources of losses produced by sugar mills. This research studied the effects of losses on the 
efficiency of the sugar mills and their losses caused by the losses. Another difference is that this study also analyzed the risks caused by the losses.

If the losses generated by sugar mills are greater than $2 \%$, it will cause losses to sugar mills, and this is the risk faced by the sugar mills. Therefore, an analysis on the risk of production due to losses is important to be conducted. The aims of this study are to (1) analyze the value of loss index and its implications on the efficiency of sugar mills and (2) to assess the magnitude of risk due to losses.

The scope of the problem in this study was limited to be more targeted and easy to understand. The research focused on the analysis of the magnitude of the loss index produced by the 11 sugar mills of PT. Perkebunan Nusantara $X$ and to identify the impact of the losses on the efficiency and performance of the sugar mills. In the next section, an analyses on the risks faced by sugar mills due to losses and on risk management that can be carried out by the mills to control losses were carried out.

\section{METHODS}

Sources of data in this study were primary data and secondary data. The primary data in the form of information were obtained by conducting interviews with the experts who understood the national sugar. The secondary data were time series data of the indicators of the performance of the 11 sugar mills of PTPN X (period 2011-2015). The secondary data were also obtained from relevant documents, literature, scientific journals, and reports.

The index calculation was used to analyze the loss index of the sugar mills by using the following formula:

Loss index $=\Sigma$ losses $/ \Sigma$ milled sugar cane

Standard value of loss index is expected to be less than $2 \%$ while the percentage of losses was calculated as follows:

$\%$ losses in blotong $=\Sigma$ sugar in blotong $/ \Sigma$ losses $\mathrm{x}$ $100 \%$

$\%$ losses in mollase $=\Sigma$ sugar in mollase $/ \Sigma$ losses $\mathrm{x}$ $100 \%$
$\%$ losses in bagasse $=\Sigma$ sugar in bagasse $/ \Sigma$ losses $\mathrm{x}$ $100 \%$

$\%$ unknown losses $=\Sigma$ unidentified sugar $/ \Sigma$ losses x $100 \%$

The implications of losses on the performance and efficiency of sugar mills were analyzed using the causative descriptive analysis. Meanwhile, to identify losses of sugar mills due to the magnitude of losses was analyzed by calculating the amount of losses as follows:

Losses due to losses $=\Sigma$ unknown losses $\mathrm{x}$ HPP of each sugar mill

Furthermore, the method of failure mode and effect analysis (FMEA) was used to analyze the value of production risk due to losses. In FMEA method, three parameters (severity, occurrence, and detection) were used to describe each failure mode according to the assessment on a scale of $1-10$. The severity rating is the seriousness of the failure effect due to losses. The incidence rate is the possibility or frequency of occurrence of risk due to losses with 1 representing the least chance of occurrence and 10 being the highest occurrence. Detection rate is the inability to detect failure or probability of undetected failure before impact of risk effect.

According to Chen (2007) and Kristiyanto et al. (2015), FMEA assessments were performed using the risk priority number (RPN). RPN is the products of severity $(\mathrm{S})$, occurrence $(\mathrm{O})$, and detection (D) calculated by following the equation:

$$
\mathrm{RPN}=\mathrm{S} \times \mathrm{O} \times \mathrm{D}
$$

A failure mode has a higher RPN value which is assumed to be more important and given higher priority for corrective action than that with a lower RPN.

According to Hallikas et al. in Suharjito (2011), a common risk management process in a company consists of four main activities: 1) Risk identification. By identifying the risks, an event or phenomenon which causes uncertainty can be identified. This risk identification aims to recognize the uncertainty that will occur so that it can be controlled. 2) Risk assessment. This activity is required to select the appropriate management action toward the identified risk factors based on the condition and situation of the company. 
3) Decision and implementation of risk management measures. Risk management can be undertaken by avoiding risk, mitigation or risk elimination, risk transfer, and/or risk absorption or risk pooling. 4) Risk control. Risk factors should be identified and should be monitored to identify the increase in the potential of risks which may occur and to face the consequences and possibility of new risk factors that may arise later. The research model (Figure 1) and the hypothesis of this study are as follows:

H1 : Loss index generated by the sugar mills in PTPN X is greater than $2 \%$ resulting in implications for poor efficiency and performance of the sugar mills.

$\mathrm{H} 2$ : The result of FMEA analysis shows risk categorization due to losses i.e sugar quality risk, raw material quality risk, production cost risk, and transportation risk which belongs to a very high risk category.

\section{RESULT}

\section{Value of Loss Index and Its Implication on Sugar Mill Efficiency}

Analysis on the magnitude of loss index produced by the sugar mills and sources of losses i.e. sugar content attached to blotong, molasses, bagasse, or unknown materials. One indicator to measure the efficiency of a sugar mill is to analyze the amount of sugar-containing material loss during processing known as losses. In this research, the analysis on the magnitude of loss index produced by sugar mills and from the sources of losses of blotong, molasses, bagasse or unknown materials was conducted.

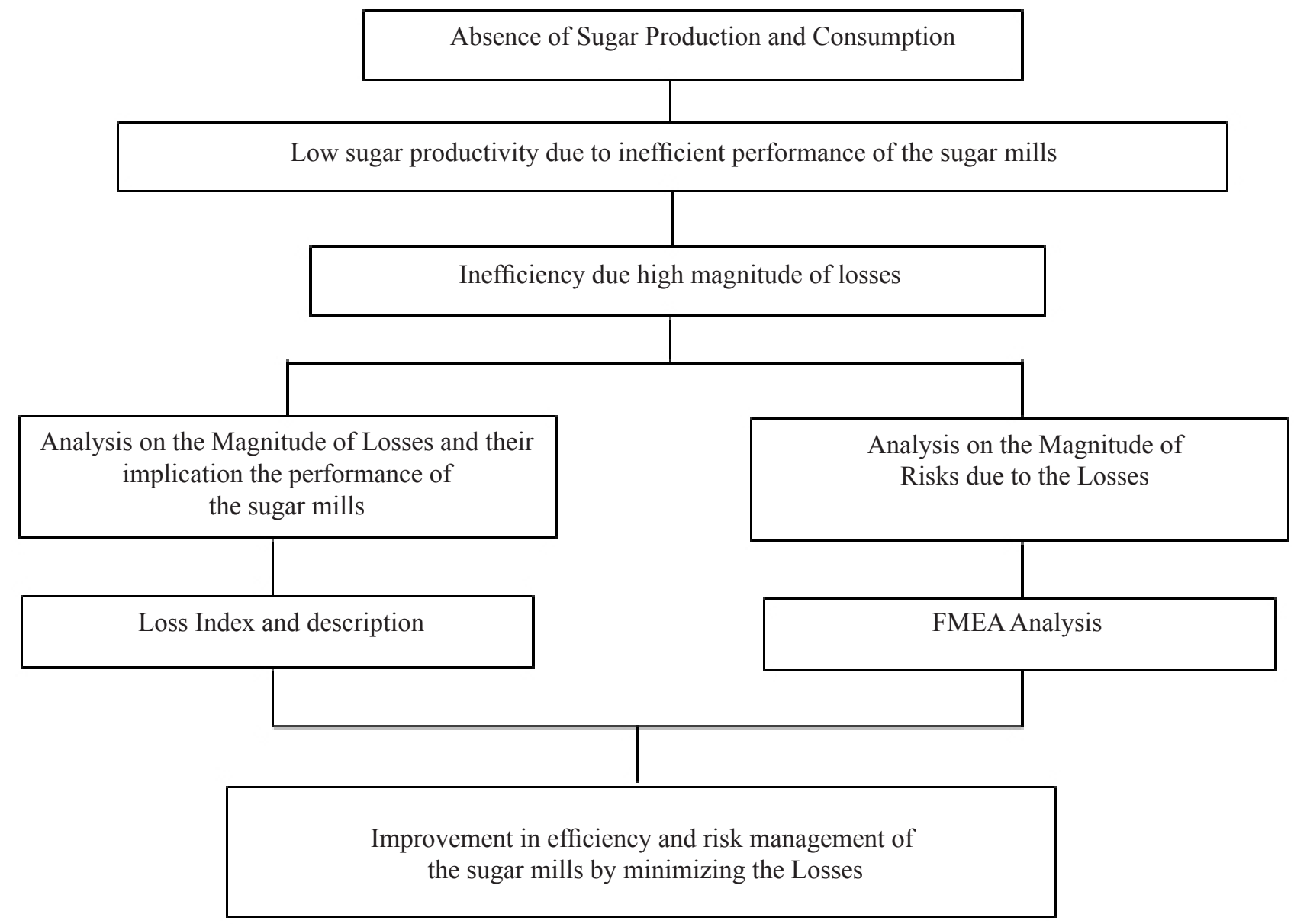

Figure 1. Research framework 
The analysis results of Loss Index of all sugar mills located in PTPN X show that the magnitude of losses among the sugar mills is different. The average loss index value of sugar mills in PTPN X is relatively large, ranging from 0.0248 to 0.0288 (2.48\% to $2.88 \%$ of the total milled sugar cane). The index value is relatively high when compared with the standard Loss Index below 2\%. A high Loss Index indicates that the level of losses of sugar-containing materials at the sugar mills of PTPN X is still high. High losses lead to inefficient performance of the sugar mills and indicate an unfavorable condition of the mills.

The losses at the processing station can happen at the purifying station where the sugar content is attached to the bagasse, blotong, and molasses at the final station. The high loss index produced by most sugar mills can be caused by the condition of machines that are mostly old and have no optimal performance. Sugar losses at the processing station can occur at the purification station, where sugar content is attached to bagasse and blotong along with the molasses at the final station. Another loss that occurs at the processing station and is difficult to control is unknown loss (due to mechanics or chemicals). This is in accordance with the research by Wibowo (2007) who states that the largest loss occurs at the processing station of a sugar mill (PG).

Based on the value of Loss Index in Table 1, it is known that the sugar mills in PTPN X that have the highest loss value include the Sugar Mills of Kremboong, Gempol Krep, Djombang Baru and Watoetoelis. Nevertheless, all sugar mills in PTPN X still have the loss index above $2 \%$. This indicates that the sugar mills are still inefficient in the processing of sugar cane into sugar where much of the sugar content is attached to other materials such as blotong, molases, ampas and other unknown materials.

Most of the losses are sourced from molasses ranging from $50 \%$ to $67 \%$, from bagasse (18-21\%), blotong $( \pm 2 \%)$ and sugar lost by mechanical or chemical problem/unknown losses (9-23\%). The unknown losses in Sugar mills in PTPN X are relatively large. The result is relatively larger when compared to the study by Sharma and Kumar (2015) that found that the unknown losses in the sugar mills in Punjab India were only $4.83 \%$. The high unknown losses can lead to inefficiencies and losses in sugar mills. These unknown losses need to be minimized by the sugar mills to reduce their inefficiency.

The magnitude of losses attached to the molassess is not a disadvantage because the molassess still have a sale value. Losses that are attached in the bagasse also still have a sale value because it can still be used as a coproduct or sold. Similarly, the losses that are attached in blotong also can still be used as a co-product of sugar mills in order to avoid losses. Some losses are identified as unknown losses (due to mechanical or chemical problem) If they are calculated in rupiah, they will cause losses, and this is a risk faced by sugar mills.

\section{Table 1. Loss Index and sources of sugar mills losses in PTPN X}

\begin{tabular}{lccccc}
\hline \multirow{2}{*}{ Name of PG } & Indexs of & \multicolumn{4}{c}{ Source of Losses (\%) } \\
\cline { 3 - 6 } & Losses & Bagasse & Blotong & Molasses & Unknown \\
\hline Watoetoelis (WT) & 0.0288 & 18.33 & 2.09 & 59.21 & 20.36 \\
Toelangan (TL) & 0.0252 & 20.94 & 2.39 & 58.09 & 18.59 \\
Kremboong (KR) & 0.0262 & 20.31 & 2.32 & 61.80 & 15.57 \\
Gempol Krep (GK) & 0.0269 & 19.68 & 2.25 & 62.85 & 15.22 \\
Djombang Baru (DB) & 0.0277 & 19.02 & 2.17 & 55.36 & 23.46 \\
Tjoekir (TK) & 0.0253 & 20.94 & 2.39 & 61.53 & 15.14 \\
Lestari (LS) & 0.0244 & 21.62 & 2.47 & 64.24 & 11.67 \\
Meritjan (MR) & 0.0248 & 21.28 & 2.43 & 66.96 & 9.33 \\
Pesantren Baru (PB) & 0.0254 & 20.74 & 2.37 & 61.45 & 15.45 \\
Ngadirejo (NG) & 0.0252 & 20.90 & 2.38 & 54.93 & 21.79 \\
Mojo Panggung (MP) & 0.0252 & 20.84 & 2.38 & 61.38 & 15.41 \\
PTPN X (NX) & 0.0260 & 20.22 & 2.31 & 60.04 & 17.44 \\
\hline
\end{tabular}

Source: Production Data PTPN X 2011-2015 
The high losses will have implications on the performance and efficiency of the sugar mills where the indicators of performance and efficiency of sugar mills can be explained from the indicators of mill extraction (ME), boiling house recovery (BHR), overall recovery (OR). The performance and efficiency indicators are strongly influenced by the magnitude of losses produced by sugar mills. The high value of losses will indicate the low values of $\mathrm{ME}, \mathrm{BHR}$ and $\mathrm{OR}$.

The sugar content losses derived from the bagasse, blotong, molassess or unidentified matters that occur at the processing station will have implications for the low efficiency of the processing station (BHR). Low BHR values indicate a high amount of sugar loss. This is consistent with Wibowo (2007) who states that a low $\mathrm{BHR}$ value indicates that at the processing station there has been a significant loss of sugar content (high losses). The implication is that the performances of milling stations (ME) and processing (BHR) are low due to high losses, thus causing low efficiency of the sugar mills in East Java (OR) (below standard). This can be seen in Table 2.

Table 2 implies that the sugar mill efficiency indicator has the opposite relationship to the value of losses, where the magnitudes of ME, BHR, OR and Sugar cane Pole will decrease if the resulted loss value increases. Moreover, Table 2 shows that the e sugar mills in the PTPN X environment have not shown the efficiency condition in which the value of the efficiency indicator that is produced is still below the standard such as ME of $92.63 \%(<96 \%)$, BHR of $82.02(<91 \%)$, OR of $74.50 \%(<87.5 \%)$ and sugar cane pole of $10.33(<12 \%)$. This shows that the performance of sugar mills has not been optimal and inefficient. The research by Sawit et al. (2003) shows that the inefficiency of processing is caused by the relatively large losses in the processing station. Unoptimal performance will result in low cost efficiency (low yield, high cost of sugar production). This is consistent with the study by Hariadi (2015) who states that sugar refined rate in general still ranges from $6 \%$ to $9 \%$, so that local sugar production cost is still expensive, and it is difficult to compete with sugar industry of other countries which have yield/bagasse level up to $12 \%$.

Losses generated by each sugar mill can also show competitiveness if the magnitude of losses is compared with the magnitude of losses of sugar mills of other sugar producers in the world, such as Thailand and India. The national sugar mills in general still have high losses.
Based on Table 3, it shows that the value of the losses of sugar mills in PTPN X ranged from 2.44 to $2.88 \%$ (average of $2.6 \%$ ), while the average value of the losses of the national sugar mills was around 2.5-3\%. The loss values of sugar mills in PTPN and in national sugar mills as a whole are still higher than those of other sugar producing countries such as India and Thailand. The sugar mills in these countries have been efficient where the value of losses produced is $<2 \%$ i.e. smaller than the average world losses of $2 \%$. This is why both countries have their competitiveness to contribute to world sugar production. The inefficiency of the national sugar mills is due to the fact that many sugar mills use old machinery, causing a lot of leakages or losses of sugar in processing. In addition, the scale or capacity of the national sugar mill production is also low compared to that of other countries that have more efficient production.

Table 2. Efficiency indicators of sugar mills in PTPN X

\begin{tabular}{lcc}
\hline \multicolumn{1}{c}{ Indicators } & Value at sugar mills & Standard \\
\hline ME (\%) & 92.63 & $>96$ \\
BHR (\%) & 82.02 & $>91$ \\
OR (\%) & 74.50 & $>87.5$ \\
Pol \% tebu & 10.33 & $>12$ \\
Losses (\%) & 2.60 & $<1,5$ \\
\hline
\end{tabular}

Source: Production Data PTPN X 2011-2015

Table 3. Comparison of losses of national sugar mills with other manufacturers in the world

\begin{tabular}{lc}
\hline \multicolumn{1}{c}{ Name of PG } & Losses $(\%)$ \\
\hline Watoe toelis & 2.88 \\
Toelangan & 2.52 \\
Kremboong & 2.62 \\
Gempol Krep & 2.69 \\
Djombang Baru & 2.77 \\
Tjoekir & 2.53 \\
Lestari & 2.44 \\
Meritjan & 2.48 \\
Pesantren Baru & 2.54 \\
Ngadirejo & 2.52 \\
Mojo Panggung & 2.52 \\
PTPN X & 2.60 \\
Nasional & $2.50-3.00$ \\
India & $<2.00$ \\
Thailand & $<2.00$ \\
Dunia & 2.00 \\
\hline Source: Production Data PTPNX & $2011-2015$ \\
\hline
\end{tabular}

Source: Production Data PTPN X 2011-2015 and BUMN (2016) 
On the contrary, the sugar mills of Indonesia are mostly inefficient and still produce a large amount losses of sugar content during the production process, so they have low competitiveness (low yield, and high HPP). Therefore, the sugar mills must have a program to reduce their level of losses to the minimum level $(<2 \%)$ to improve competitiveness with the world sugar producing countries. The program can be an accelerated program of increasing sugar production in sugar mills by improving their performance/efficiency through rehabilitation and/or upgrading of milling technology, milling capacity optimization, and reduction of overall recovery hours.

If analyzed economically, the lost sugar content on processing due to losses derived from the bagasse, molasses and blotong still has a selling value and value added. The critical point is the losses found in the sugar value whose loss was unknown (due to mechanical or chemical matter) which can cause harm to the sugar mills. The following is the calculation of the value of losses caused by the unknown losses.

Table 4 shows that the loss value due to unknown losses has a relatively high nominal value. The loss is derived from the lost sugar value multiplied by the HPP of each sugar mill. The value of losses experienced by PTPN sugar mills ranged from 2.34 to $7.66 \%$ of the total profits of the sugar mills. The largest value of sugar mills losses in PTPN X was experienced by Sugar Mill of Ngadiredjo, while the lowest one was experienced by Sugar Mill of Meritjan. If calculated in total for the sugar mills in PTPN X, the plantation suffered losses of Rp163,802,711,586.62 (4.8\% of total profits earned by PTPN X). This represents a large proportion of losses due to the unknown losses. The study by Sharma and Kumar (2015) also shows the same thing that is if in economic value, losses in the sugar mills in India are relatively large, so there is a need to control the unknown losses.

In addition to calculating the value of sugar loss due to mechanical or chemical matter (unkown), losses of sugar mills can also be calculated by analyzing or comparing the loss value of sugar contents attached to molasses or molasses. The losses were calculated by converting the value of losses of molasses into sugar value, and then it was compared to the selling value of the molasses themselves.

In Table 5, it is explained that if the sugar cane processing molassess are sold at a price of $\mathrm{Rp} 1,000$ and if compared with the value of sugar that is attached to the molassess, the selling value of sugar in the molassess obtained is greater (2-3 folds) than the selling point of the molassess. This implies that economically, sugar mills are still inefficient and experience loses if they sell only molassess. Therefore, the processing of molassess into co-products with added value is required.

Table 4. Losses due to Losses

\begin{tabular}{lccc}
\hline \multicolumn{1}{c}{ Name of PG } & HPP (Rp) & Losses (Rp) & Loss (\%) \\
\hline Watoetoelis (WT) & 9,636 & $18,178,486,406.39$ & 7.42 \\
Toelangan (TL) & 12,208 & $10,210,272,252.57$ & 6.88 \\
Kremboong (KR) & 9,981 & $17,979,613,990.55$ & 6.29 \\
Gempol Krep (GK) & 5,742 & $19,648,182,839.00$ & 3.84 \\
Djombang Baru (DB) & 9,291 & $20,611,424,030.13$ & 7.66 \\
Tjoekir (TK) & 7,803 & $18,745,256,648.21$ & 6.00 \\
Lestari (LS) & 6,921 & $11,629,313,423.45$ & 3.64 \\
Meritjan (MR) & 7,000 & $6,006,187,805.23$ & 2.34 \\
Pesantren Baru (PB) & 5,484 & $19,365,234,058.27$ & 4.09 \\
Ngadirejo (NG) & 4,895 & $23,687,275,788.81$ & 5.08 \\
Mojo Panggung (MP) & 5,723 & $10,704,099,837.27$ & 3.79 \\
PTPN X (NX) & 6,265 & $163,802,711,586.62$ & 4.80 \\
\hline
\end{tabular}

Source: Production Data PTPN X 2011-2015 
Table 5. Losses of Molassess

\begin{tabular}{lcc}
\hline \multicolumn{1}{c}{ Name of PG } & The selling value of molassess (Rp) & The selling value molassess of molassess (Rp) \\
\hline Watoetoelis (WT) & $20,342,377,750$ & $51,584,083,334$ \\
Toelangan (TL) & $9,947,202,250$ & $30,115,708,287$ \\
Kremboong (KR) & $19,251,600,500$ & $50,359,693,852$ \\
Gempol Krep (GK) & $59,414,636,500$ & $89,086,715,967$ \\
Djombang Baru (DB) & $22,499,945,000$ & $54,320,460,053$ \\
Tjoekir (TK) & $30,989,485,000$ & $60,748,781,948$ \\
Lestari (LS) & $33,159,790,250$ & $59,962,263,728$ \\
Meritjan (MR) & $26,836,232,500$ & $48,817,648,969$ \\
Pesantren Baru (PB) & $57,674,625,000$ & $83,167,537,848$ \\
Ngadirejo (NG) & $54,380,512,500$ & $69,638,670,488$ \\
Mojo Panggung (MP) & $28,647,117,750$ & $43,100,342,480$ \\
PTPN X (NX) & $363,889,627,500$ & $598,184,412,557$ \\
\hline
\end{tabular}

Source: Production Data PTPN X 2011-2015

\section{Risk Assessment due to the Magnitude of Losses with Failure Mode and Effect Analysis (FMEA) Method}

Losses are the losses of sugar contents attached to byproducts such as molasses, bagasse, blotong and the unknown losses. If the sugar content losses are calculated in rupiahs, they will cause losses for the sugar mills; therefore, they represent risks that must be minimized by the sugar mills.

Based on the results of literature and brainstorming studies, as well as in-depth interviews with the experts, a framework for identifying production risks at sugar mills was obtained (Figure 2). This structure consists of 3 clusters, namely:

1. Risk source cluster: the sources of loss risk due to losses in this study are divided into several sources i.e. losses from the sugar content attached to blotong, molasses and bagasse and unidentified losses.

2. Risk factor cluster: the risk due to losses can be caused by several factors such as the quality of raw materials, condition of the sugar mills, magnitude of losses, and production cost (HPP).

3. Sugar mill efficiency indicator cluster: efficiency indicators that play a role in the level of risk of sugar production include ME, BHR, OR and sugar cane poles.

According to Aini et al. (2014), risk analysis is performed to differentiate acceptable minor risks from major risks, as well as to provide data that will assist the assessment and risk control phases. The risk assessment phase in this research was assisted by Failure Mode and Effect Analysis (FMEA) method. Three components of severity, occurence, and detection produced a Risk Priority Number value. The result of the risk assessment from the experts' opinions can be seen in Table 6 .

Risk assessment was conducted by comparing the risk levels that had been calculated in the risk analysis stage with the standard criteria used. The RPN value was used to represent priority on correction actions on a scale of 1-1000, which can be categorized into five interval classes described in Table 7.

Table 6 shows that the very low risk is sugar quality (average RPN of 37). The quality of sugar produced by the sugar mills is still guaranteed despite the relatively low factory performance. The medium-risk category is the risk of raw material quality (average RPN of 147). Currently, the biggest problem in improving the quality of sugar cane raw materials is related to the management of felling, loading and transport of sugar cane and poor maintenance which lead to the decreasing quality of sugar cane. In addition, the SCF requirement (sweet, clean, and fresh) is often not met, and other implication is that the yield produced is low. However, the risk of raw material quality is still categorized as medium because the critical point is on the sugar mills themselves.

Risks categorized to be high are production cost risk (average RPN of 165) and transport risk (average RPN of 156). It is undeniable that the production process of the sugar industry in SOEs is still inefficient. This 
inefficiency makes production cost very high and far from the word of "economical". In SOEs, sugar production cost once reached Rp. 6,860 perkilo, whereas at the ideal level, the cost of producing sugar should only be around Rp. 5,813 per kg. In addition, transportation risk is also high due to the inefficient transportation process from the farm land to mills in which sugar cane sometimes shrinks since the distance between the farm land and the intended mill is great.
Risk sources due to Losses: Blotong, Bagasse, Molasse/ molasses, Unknown Losses
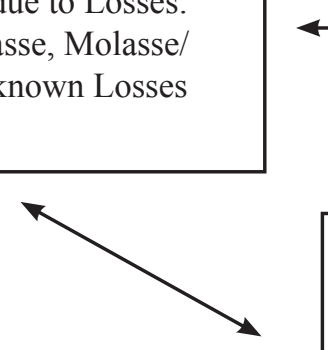

Risk Factors:

Quality of sugar cane raw material, Condition of the Sugar Mills, Magnitude of Losses, Production Cost (HPP)
Efficiency Indikators of the Sugar Mills: ME, BHR, OR, Sugarcane Pol

Figure 1. FMEA Model analysis framework

Table 6. Failure Mode and Effect Analysis Table (FMEA)

\begin{tabular}{|c|c|}
\hline Risk factor & Risk variables \\
\hline \multirow[t]{7}{*}{ Raw material quality } & Criteria of sweet, clean, and fresh are sometimes not fulfilled \\
\hline & Unpredictable climate and weather \\
\hline & $\begin{array}{l}\text { Loss of sugar that is relatively large during transportation due to the inadequate management } \\
\text { of felling, hauling, and loading }\end{array}$ \\
\hline & Low sugar cane productivity \\
\hline & Less sustainable continuity of raw materials \\
\hline & Reasonably various quality of sugar cane \\
\hline & Less timely input, quantity, price and quality \\
\hline \multirow[t]{6}{*}{ Condition of Sugar Mills } & Low milling capacity \\
\hline & Substandard Performance and Efficiency of Sugar Mills \\
\hline & Old Machinery of Sugar Mills \\
\hline & High frequency of mill shut-offs \\
\hline & High utilization of steam and fuel \\
\hline & High magnitude of losses \\
\hline \multirow[t]{2}{*}{ Existence of Losses } & Loss dues to high losses \\
\hline & Relatively low sugar quality (the value of ICUMSA is above 150) \\
\hline \multirow[t]{3}{*}{ Quality of Sugar } & Low yields \\
\hline & Decreasing quality of products \\
\hline & High production cost due to inefficiency \\
\hline \multirow[t]{2}{*}{ Production cost } & HPP becomes higher \\
\hline & Damage of Infrastructure \\
\hline \multirow[t]{2}{*}{ Transportation } & Inaccuracy in time \\
\hline & Long distance of transportation \\
\hline
\end{tabular}


Table 7. Risk Category based on RPN

\begin{tabular}{lll}
\hline Rpn value & Risk category & Risk control \\
\hline $1-50$ & Very low & Accepting \\
$51-100$ & Low & Accepting \\
$101-150$ & Medium & Avoiding \\
$151-200$ & High & Mitigation \\
$201-250(>250)$ & Very high & Mitigation \\
\hline
\end{tabular}

Risks that falls into a very high category are the risk of the sugar mill condition that arises during sugar cane processing (average RPN of 252) and the risk of losses (average RPN of 226). The latent problem that increasingly makes the industry performance is unoptimal is the inefficiency in the sugar mills. In regards to sugar cane processing, almost in all SOEs, inefficiency in milling station, refining station, steaming station, cooking station, and rotation station still occur. The sugar mills of the SOEs are currently equipped with old machines with a milling capacity of about 3,500 tons per day (TCD) so that they cannot reach their economic scale. Inefficiency in these sugar mills are also caused by high frequency of mill shut-offs due to unfavorable milling days; in addition, critical inefficiency point occurs due to high production and consumption costs of steam and fuel since billions of rupiahs are spent on fuel purchases (Subiyono, 2014). In addition to the mill condition, the engine performance is unoptimal causing a lot of sugar content to be attached to the side products such as bagasse, molasses, and blotong (losses are also high). Losses generated by the sugar mills of PTPN X have reached $2.6 \%$ (high category), and the losses can also reach $4 \%$ of the total income of the sugar mills.

\section{Managerial Implication}

Determination of appropriate action to be taken in risk management of sugar production due to the losses refers to the results of risk identification and assessment that had been previously conducted. Some risk control measures are a mitigation process that can be implemented based on the biggest risk priority i.e. the risk at the processing stage (risk on the condition of the sugar mills and the presence of losses). The risk management that can be implemented can be seen in Table 8 .

The risk management that can be applied to reduce the level of risk in sugar cane processing into sugar is to revitalize the sugar mills by performing repairs and replacement of the equipment whose performance has decreased and to supervise the implementation of SOP at the mills to reduce the level of sugar loss during processing. The whole sugar mill management should be committed to improve the performance of the sugar mills, and there is a need for an overall mill audit from steam generating station, grinding station and processing station to find out the sources of sugar loss and sugar mill inefficiency.

Table 8. Risk control strategies

\begin{tabular}{|c|c|c|}
\hline Problems & Risks & Managerial implications \\
\hline $\begin{array}{l}\text { Optimization of raw } \\
\text { material quality }\end{array}$ & Raw material quality risk & $\begin{array}{l}\text { Guidance on sugar cane farmers to apply GAP, cut down } \\
\text { sugar cane at the optimum maturity level, supervise the } \\
\text { application of SOP of sugar cane cultivation }\end{array}$ \\
\hline $\begin{array}{l}\text { Increased productivity of } \\
\text { sugar cane }\end{array}$ & Raw material quality risk & $\begin{array}{l}\text { The use of superior varieties, improved mastery of } \\
\text { cultivation technology, unloading ratoon after } 2 \text { times of } \\
\text { keprasan }\end{array}$ \\
\hline $\begin{array}{l}\text { Improved freight } \\
\text { management }\end{array}$ & $\begin{array}{l}\text { Raw material quality risk and } \\
\text { transportation risk }\end{array}$ & Improved slash-haul management \\
\hline $\begin{array}{l}\text { Increased efficiency/ } \\
\text { performance of sugar } \\
\text { mills }\end{array}$ & $\begin{array}{l}\text { Sugar mill condition risk, } \\
\text { sugar quality risk, loss risk, } \\
\text { production cost risk }\end{array}$ & $\begin{array}{l}\text { The need for repairs or replacement of equipment in the } \\
\text { sugar mills. It is necessary to apply new technologies to } \\
\text { improve their performance, and operational supervision and } \\
\text { commitment of all levels of the sugar mill management and } \\
\text { audit on the sugar mills are also required }\end{array}$ \\
\hline $\begin{array}{l}\text { Increased milling } \\
\text { capacity/mills }\end{array}$ & $\begin{array}{l}\text { Sugar mill condition risk, } \\
\text { sugar quality risk, loss risk, } \\
\text { production cost risk }\end{array}$ & $\begin{array}{l}\text { Optimization of small sugar mill capacity } \\
\text { Improved maintenance of sugar mills } \\
\text { In the long run, there is a need to improve/replace the small } \\
\text { capacity into large capacity of the sugar mills }\end{array}$ \\
\hline
\end{tabular}




\section{CONCLUSIONS AND RECOMMENDATIONS}

\section{Conclusions}

The average value of the sugar mill Loss Index in PTPN X is relatively large at $2.6 \%$ (above the standard $<2 \%$ ), indicating that the condition of the sugar mills is inefficient. The sources of losses include molasses (50$67 \%$ ), bagasse (18-21\%), blotong (2\%), and unknown losses (9-23\%). The high losses will have implications on the performance and efficiency of the sugar mills where performance and efficiency indicators of sugar mills can be explained from the indicators such as mill extraction (ME), boiling house recovery (BHR), overall recovery (OR). The high value of losses will indicate the low values of ME, BHR and OR. The contents of the losses coming from the bagasse, blotong, molasses or unidentified losses that occurred at the processing station will have implications for the low efficiency of the processing station (BHR). The low BHR value indicates a high amount of sugar loss. The implication is that the performance of milling stations (ME) and milling processing (BHR) is low due to high losses that cause low efficiency of the sugar mills of East Java (OR) (below standard).

Failure Mode and Effect Analysis (FMEA) was used as a way of assessing production risks at sugar mills due to losses starting from examining the causes of failure, severity level and its impact, and by calculating Risk Priority Numbers (RPNs), it gives assisstance in determining appropriate actions to reduce impacts of the risks. The FMEA analysis results show risk categorization including the highly low risk of sugar quality risk (average RPN of 37), medium risk category of raw material quality risk (average RPN of 147), high risk category of production cost risk (average RPN of 165 ) and transport risk (average RPN of 156), and very high risk category of sugar mill condition (average RPN of 252) and loss risk (average RPN of 226).

\section{Recommendations}

The sugar mills must have a program to reduce the level of losses to the minimum $(<2 \%)$. Programs that can be implemented by th sugar mills include the acceleration program to increase sugar production in the mills by improving their performance/efficiency through rehabilitation and/or upgrading of factory technology or replacement of old equipment or machinery, milling capacity optimization, and reduction in tihe number of hours when the milling machine stops working (overall recovery).

The risk management that can be applied to reduce the level of risk in sugar cane processing into sugar is to revitalize the sugar mills by performing repairs and replacement their equipment that has decreased its performance and to supervise the implementation of SOP at the mills to reduce the level of sugar loss during processing.

\section{ACKKNOWLEDGEMENT}

The author would like to thank PTPN X for its assistance in providing the research data.

\section{REFERENCES}

Aini H, Syamsun H, Setiawan A. 2014. Risiko rantai pasok kakao di indonesia dengan metode analytic network process and failure mode effect analysis terintegrasi. Jurnal Manajemen dan Agribisnis 11(3): 209-219.

Bantacut T. 2010. Swasembada gula: prospek dan strategi pencapaiannya. Pangan 16(3): 245256.

Bantacut T. 2013. Pengembangan pabrik gula mini untuk mencapai swasembada gula. Pangan 19 (3): 245-256.

Bhagat JJ. 2012. National Plan for Improving Efficiency in Indone-sian Sugar Industry-Field \& Factory. New Delhi: STM Projects Limited.

Cahyati S. 2012. Rekayasa model penilaian kinerja operasional pabrik gula berbasis ecomaintenance [disertasi]. Bogor: Institut Pertanian Bogor.

Chen JK. 2007. Utility priority number evaluastion for FMEA. Journal of Failure Analysis and Prevention 7(5): 321-328. https://doi. org/10.1007/s11668-007-9060-2.

Fahriyah, Asmara R, Hanani N. 2012. Tingkat Penerapan Teknologi Petani dalam Usahatani Tebu. Ekonomi Gula. Jakarta: PT Gramedia.

Hariadi, B. 2015. Revitalisasi pabrik gula milik negara dalam jeratan decoupling. Jurnal Akuntansi Multiparadigma 6 (2): 304-315. https://doi. org/10.18202/jamal.2015.08.6024.

Hartono. 2012. Efisiensi Produksi Tebu dan Gula Indonesia. Ekonomi Gula. Jakarta: PT. Gramedia. 
Jati K. 2013. Sugar price analysis in Indonesia. International Journal of Social Science and Humanity3(4):369-374.https://doi.org/10.7763/ IJSSH.2013.V3.264.

Kementerian BUMN RI. 2016. Road Map Komoditi Tebu Nasional 2016-2019. Jakarta: Kementerian BUMN RI.

Kristiyanto R, Sugiono, dan Yuniarti R. 2015. Analisis risiko operasional pada proses produksi gula dengan menggunakan metode Multi-Attribute Failure Mode Analysis (MAFMA) (studi kasus: PG. Kebon Agung Malang). Jurnal Rekayasa Dan Manajemen Sistem Industri 3(3):592-601.

Marta S. 2011. Analisis efisiensi industri gula di Indonesia dengan metode Data Envelopment Analysis (DEA) Tahun 2001-2010. Media Ekonomi 19(1): 71-88.

Neves M, Vinicius GT, Consoli M. 2009. The sugar energy map of Brazil. http://www.sugarcane.org. [15 Juni 2016].

Sawit MH. 2010. Kebijakan swasembada gula apanya yang kurang?. Analisis Kebijakan pertanian 8(4): 283-302.

Sawit MH,KuntohartonoT, Siregar H. 2003. Penyehatan dan penyelamatan industri gula nasional. Analisis Kebijakan Pertanian 1(3): 192-209.

Sharma C, Kumar V. 2015. Quantification of sugar content loss in various by products of the sugar industry. International Journal of Advance Industrial Engineering 3(2): 50-53.
Subiyanto. 2014. Analisis efektifitas mesin/alat pabrik gula menggunakan metode overall equipments effectiveness. Jurnal Teknik Industri 16(1): 4150. https://doi.org/10.9744/jti.16.1.43-52.

Subiyono. 2014. Sumbangan Pemikiran Menggapai Kejayaan Industri Gula Nasional. Surabaya: PT. Perkebunan Nusantara X (Persero).

Sugiyanto C. 2007. Permintaan gula di Indonesia. Jurnal Ekonomi Pembangunan 8(2): 113-127. https://doi.org/10.23917/jep.v8i2.1036.

Suharjito. 2011. Pemodelan sistem pendukung psengambilan keputusan cerdas manajemen risiko rantai pasok produk/komoditi jagung [tesis]. Bogor: Program pasca Sarjana, IPB.

Supriyati. 2011. Kaji ulang konsep neraca gula nasional: konsep badan ketahanan pangan vs dewan gula Indonesia. Analisis Kebijakan Pertanian 9(2): 109-124. https://doi.org/10.21082/akp. v9n2.2011.109-124.

Susilowati SH, Trinaprilla N. 2012. Analisis efisiensi usahatani tebu di Jawa Timur. Jurnal Littri 18(4): 162-172.

Tayibnapis AZ, Sundari MS, dan Wuryaningsih. 2016. meningkatkan daya saing pabrik gula di Indonesia era masyarakat ekonomi Asean. Jurnal Riset Ekonomi dan Manajemen 16(2): 225-236. https://doi.org/10.17970/jrem.16.160205.ID.

Tinaprilla N, Ariesa FN. 2012. Komparasi Industri Gula di Beberapa Negara. Jakarta: PT Gramedia.

Wibowo R. 2007. Revitalisasi Komoditas Unggulan Perkebunan Jawa Timur. Jakarta: Perhimpunan Ekonomi Pertanian Indonesia. 